\title{
Private Pensions Market Development in Romania in 2014
}

\author{
Tudor Colomeischi \\ Stefan cel Mare University Suceava, Romania \\ Eugenia lancu \\ Stefan cel Mare University Suceava, Romania
}

\begin{abstract}
The main directions on which channeled the FSA (Financial Surveillance Authority) the activity in Romania in 2014 were the development of non-bank financial markets and their contribution to economic growth. In this article we propose an analysis of how it has evolved the private pensions market in Romania in 2014. We took into account the dynamics of assets, investments and the average rate of return of private pension funds.
\end{abstract}

Keywords: private pensions, active, investments, market, bonds, government securities

JEL classification: E2, E6

\section{Introduction}

Since 2013, the powers of the Private Pension System Supervisory Commission (PPSSC) of private pensions in Romania were taken by the Financial Supervisory Authority (FSA) in Romania "(www.csspp.ro )". Development of non-bank financial markets and their contribution to economic growth were the most important themes for the Financial Supervisory Authority of Romania in 2014. There have been drafted and launched several projects to support the two major objectives "(www.cnpp.ro )".

In private pensions, it has been launched a project to stimulate long-term savings called LIFE. This project aims at development and increasing sophistication of private pensions market to strengthen capacity for payment of adequate and sustainable pension amounts. The main components of the project stimulating savings through pension funds are complete and update the investment policy for pension funds; supporting the introduction of occupational pension funds; the legislative framework for the development of voluntary pension funds.

\section{Private pensions and pension fund assets}

The value of total assets under management throughout the private pension system increased steadily during 2014 as we can see from Figure 1, maintaining the positive trend in recent years. At 31 December 2014 the system reached 20.2 billion RON (4.5 billion Euros), representing 3.03\% of GDP compared to $2.31 \%$ in December 2013 "(INSSE, 2013-2014)". 
Figure 1

Evolution of the total assets of the private pension system in the period December 2013-December 2014

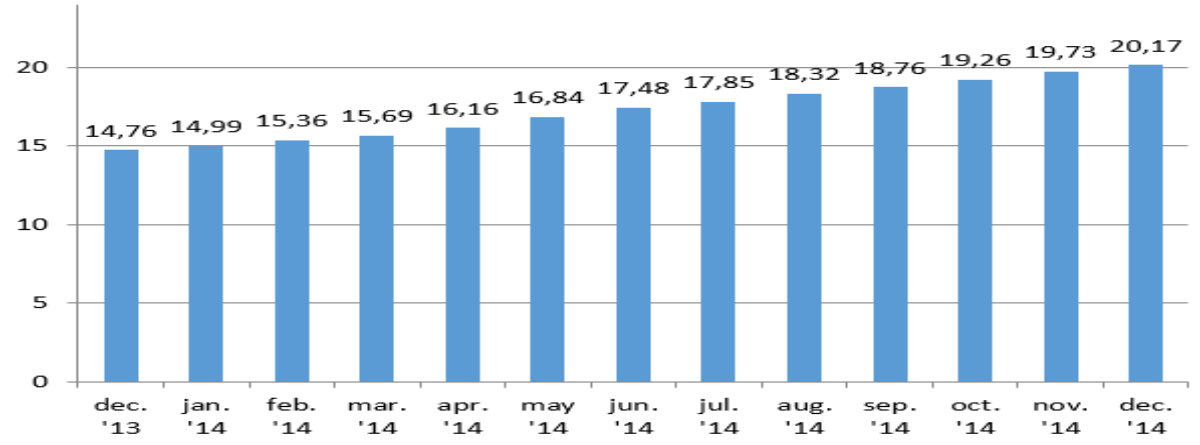

Source: Colomeischi T. (2014) - Sistemul pensiilor din România din perspectivă matematică actuarială, Editura Didactică şi Pedagogică, ISBN 978-973-30-3657-9

The annual growth rate recorded by total assets was approximately $36.65 \%$ and advances to June 2014 were $15.4 \%$ (36.73\% and $12.95 \%$ compared to euro). The monthly growth rate of total assets in the period December 2013 - December 2014 was $2.22 \%$ ( $0.91 \%$ on the euro), a value below the median review period, $2.46 \%$ in November 2013 (minimum values and maximum values recorded in 2014 were $1.58 \%$ in January and $4.16 \%$ in May) (INSSE, 2013-2014).

At the level of funding private pension (pillar II), which in 31 December 2014 accounted for almost $95 \%$ of the system, as can be seen from Figure 2, has maintained a higher annual growth rate, which is characteristic of the seven years of operation: $37.15 \%$ compared to $28.11 \%$ in Pillar III. Quarterly advances recorded growth differences: $15.56 \%$ in Pillar II and $12.6 \%$ in Pillar III.

From Figure 3 we conclude that at the end of $2014,93.2 \%$ of assets were invested in private pension system in Romania, $1.4 \%$ less than in the same period of 2013. Private pension funds continue to be a important financier of the Romanian state by investing primarily in securities issued by the Finance Ministry.

Figure 2

The structure of assets of private pension funds on two pillars on $31 / 12 / 2014$
Figure 3

The structure of the private pension system assets on $31 / 12 / 2014$
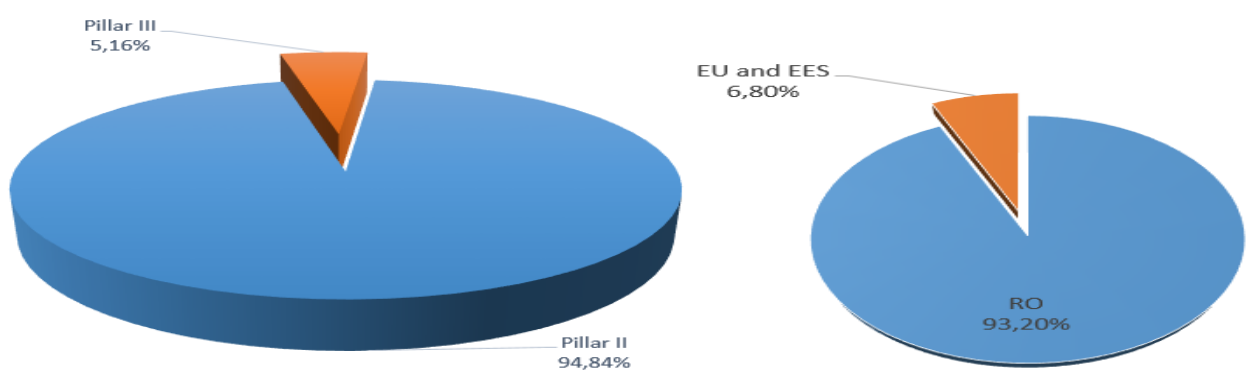

Source: Colomeischi T. (2014) - Sistemul pensiilor din România din perspectivă matematică actuarială, Editura Didactică şi Pedagogică, ISBN 978-973-30-3657-9

\section{Investments of private pension funds in 2014}

The main principles that must comply with pension companies in investing in pension fund assets are (Constantinescu, 2005): investments must be made solely in the interests of participants; investments must be made primarily in instruments traded on a regulated market; investments in derivatives are permitted only to the extent that 
contribute to lower investment risks or facilitate efficient portfolio management; assets in which is invested must be diversified properly so as to avoid excessive reliance on any particular asset, issuer or group of undertakings and accumulations of risk in the pool of assets.

Given the evolution of internal and external financial environment, the strategic asset allocation of private pension funds between different investment instruments has undergone significant changes compared to 2013. According to Figure 4, the share of bank deposits halved, while fixed weights income instruments, shares and investment funds have increased. The largest increase was in shares.

Figure 4

Strategic asset allocation of private pension funds in 2014 compared to 2013

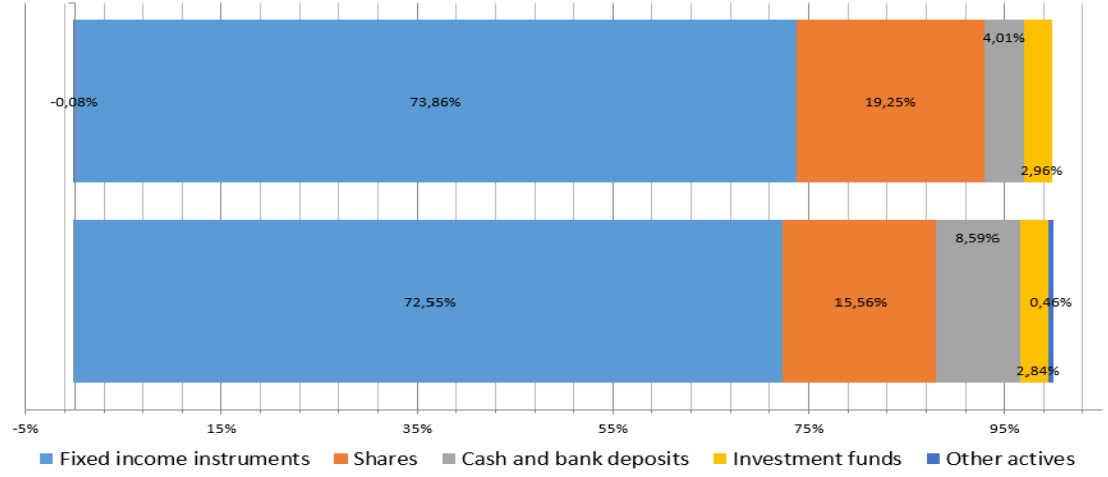

Source: Colomeischi T. (2014) - Sistemul pensiilor din România din perspectivă matematică actuarială, Editura Didactică şi Pedagogică, ISBN 978-973-30-3657-9

Administrators have continued the general trend of reducing investments denominated in lei in 2014. Compared with 2013, when $12.28 \%$ of pension funds' portfolios were denominated in other currencies at the end of 2014, as shown in Figure 5, $13.53 \%$ of assets reflected foreign currencies, of which $11.24 \%$ were denominated in euro. The weights investments in US dollar and Polish zloty fell, while administrators have opted for Turkish lira portfolios, volatile currency, but which may bring short-term gains.

Figure 5

The structure of private pension fund assets in currencies in 2014

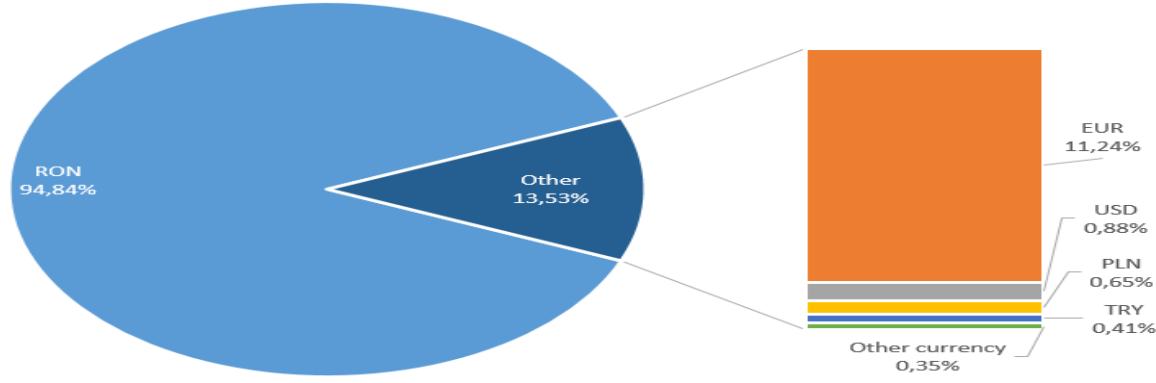

Source

Colomeischi T. (2014) - Sistemul pensiilor din România din perspectivă matematică actuarială, Editura Didactică şi Pedagogică, ISBN 978-973-30-3657-9

Currency risk was partially covered for the euro, the Hungarian forint, Polish zloty and US dollar using forward contracts concluded with banks. Coverage by hedging (Figure 6) was reduced compared to 2013 , mostly to the US dollar. 
Figure 6

Coverage of currency risk through hedging instruments

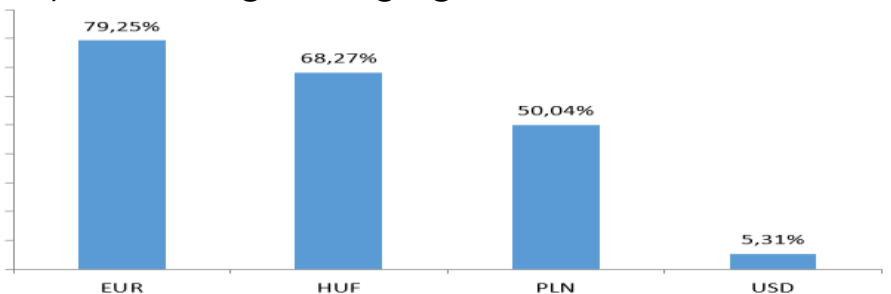

Source: www.asfromania.ro

Private pension funds investments in government securities were in percentage of $99.34 \%$ in instruments issued by the Romanian state in lei, Euros and US Dollars (Figure 7). The rest consisted of securities issued by Italy, Poland and Slovenia, their cumulative share being of less than $1 \%$ of total investments in government securities.

Figure 7

Strategic asset allocation of private pension funds in 2014 compared to 2013

Source: www.asfromania.ro

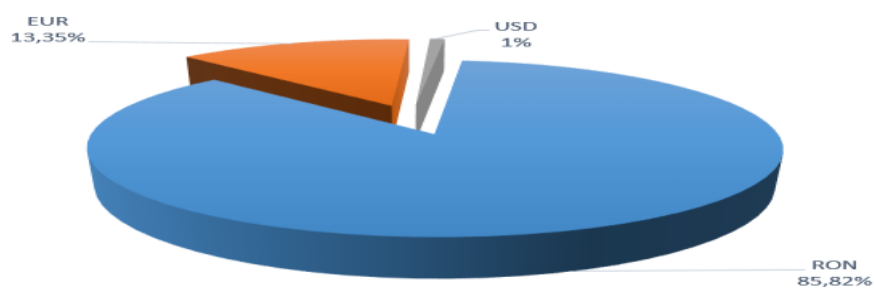

Romanian government securities accounted for $67.52 \%$ of total assets of private pension funds, suffering a slight increase compared to 2013 when their level was $66.88 \%$.

Figure 8

The maturity structure of investments in Romanian government securities (million)

Source: www.asfromania.ro

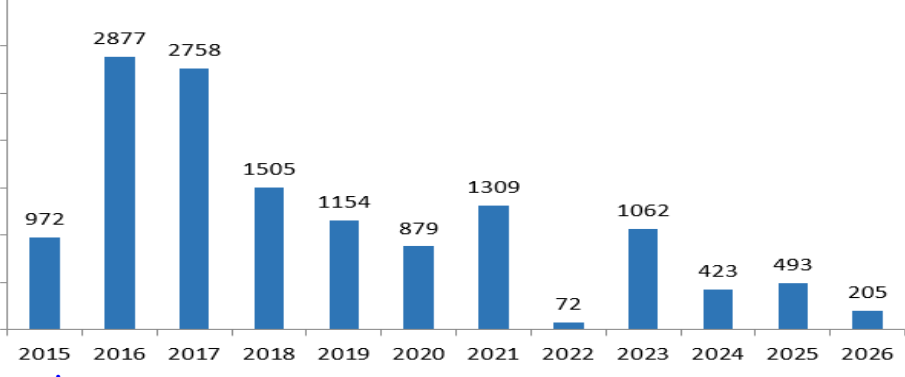

Distribution of government securities after coupon rate shows that $51.73 \%$ of these instruments were issued at an interest rate of between $5 \%-6 \%$. Compared to maturity government securities in their portfolios, according to Figure 8 , from their total, $48.52 \%$ will reach maturity by 2017 .

Corporate bonds accounted for $4.19 \%$ of the assets of the private pension system, slightly decreasing compared to 2013. 
Figure 9

The structure of corporate bonds by countries

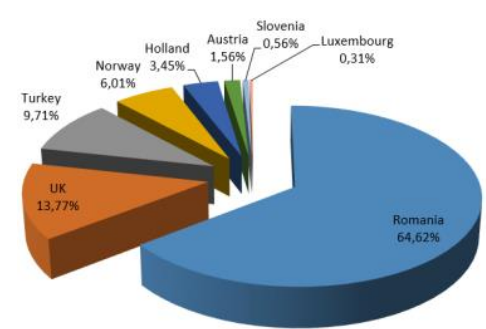

Source: www.asfromania.ro
Figure 10

The structure of investments in corporate, municipal and supranational bonds

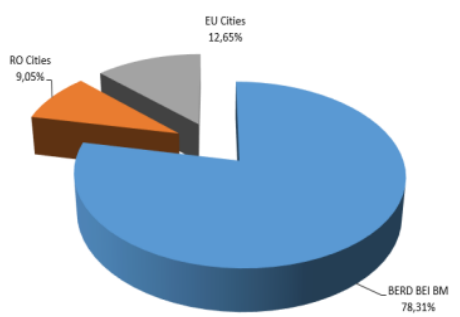

Romanian corporate bonds have increased their share from $59.48 \%$ to $64.62 \%$ of the total corporate bonds, according to figure 9. Supranational bonds accounted for $1.33 \%$ of the total assets of private pension funds, while municipal bonds had a share of $0.37 \%$. Within these, $78.31 \%$ were bonds issued by BERD, BEl and World Bank, as shown in Figure 10.

Administrators have continued to increase investment in shares in 2014 compared to 2013 from $15.56 \%$ to $19.25 \%$, focusing mainly to Romanian issuers $(86,99 \%$ in Figure 11$)$ and increased liquidity.

Figure 11

Structure of investments in shares by

countries

EU Stocks
$13,01 \%$

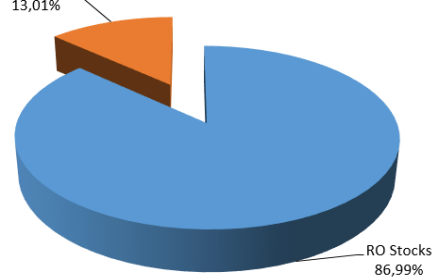

Figure 12

Structure of Romanian shares by issuers in 2014

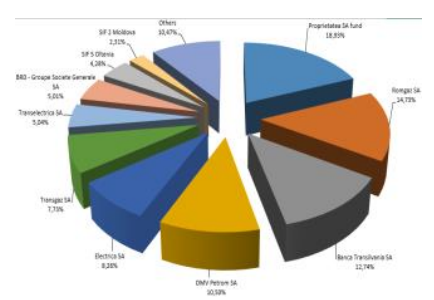

Source: $w w w . a s f r o m a n i a . r o$

Of Romanian issuers, the top ten issuers listed on the Bucharest Stock Exchange as Liquidity Fund (Property, Romgaz, Transilvania Bank, OMV Petrom, Electrica, Transgaz, Transelectrica, BRD, SIF Oltenia and SIF Moldova) accounted for $89.53 \%$ (Figure 12) of the Romanian portfolio of shares and $22.2 \%$ of the total assets of private pension funds.

Figure 13

The structure of foreign shares by issues in 2014

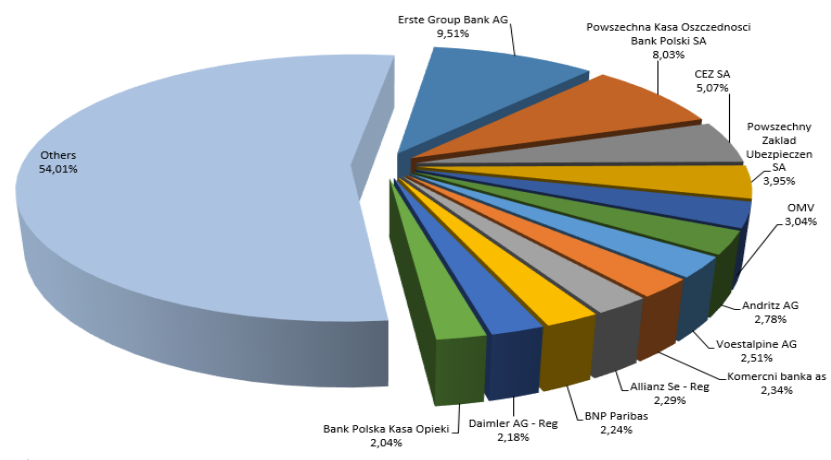

Source: www.asfromania.ro 
Due to their long-term investors, pension funds have accumulated significant holdings in companies that are top liquidity on BVB in 2014. In addition to the issuers that are in the top 10 after liquidity, pension funds have accumulated $10.47 \%$ of SIF Transilvania, $8.77 \%$ of SIF Banat Crisana and $13.07 \%$ of BSE. Investments in shares of foreign issuers were more diversified than in previous years, the largest contributors being Erste Bank with $9.51 \%$ of total foreign shares (Figure 13) and $0.24 \%$ of the total assets of private pension funds. And in 2014, pension funds have deposits at banks in Romania, $90.78 \%$ of which is denominated in lei, $7.057 \%$ in US dollars and the rest in PLN, EUR and HUF (Figure 14). The trend to reduce interest rates offered due to the expansionary monetary policy led administrators to halve the share of amounts invested in bank deposits, opting for other types of assets, mainly shares. At the end of 2014 , deposits represented only $4.01 \%$ compared to $8.59 \%$ in 2013 .

Figure 14

The currency structure of bank deposits on 31 December 2014

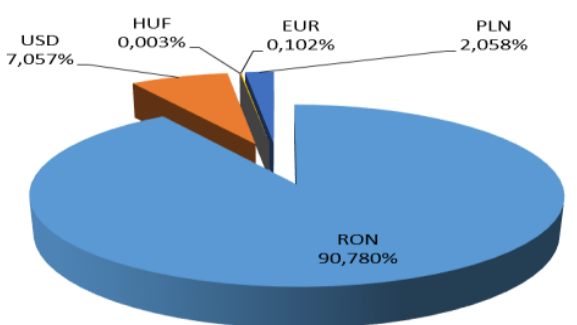

Source: Colomeischi T. (2014) - Sistemul pensiilor din România din perspectivă matematică actuarială, Editura Didactică şi Pedagogică, ISBN 978-973-30-3657-9

And in 2014, BRD was the preferred bank of administrators for setting up deposits, as shown in Figure 15. In second place BCR climbed and Garanti Bank fell to third place. Together, the three banks mentioned cumulated $71.28 \%$ of total deposits in the system, increasing compared to 2013, when the first three banks had $50.7 \%$ of the total. Compared to 2013 the share of investment funds in total assets increased slightly from $2.84 \%$ to $2.96 \%$. Administrators have preferred Romanian UCITS (Undertakings of Collective Investment in Transferable Securities) investing in bonds and shares of UCITS from European Union and Romania.

Figure 15

The structure of the bank deposits of private pension funds on 31 December 2014 compared to 31 December 2013

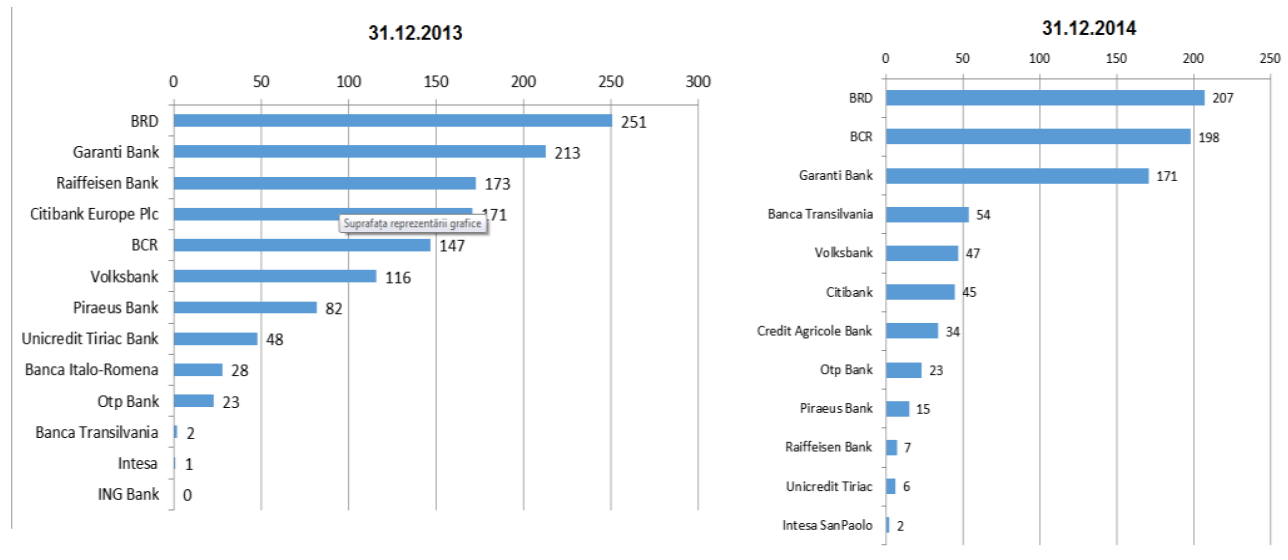

Source: www.asfromania.ro 
Due to the financial environment that continued to be characterized by declining interest rates, pension funds have achieved rates of return lower than in 2013 but real positive.

\section{Conclusions}

On December 31, 2014 the privately managed pension system (Pillars II and III) reached 20.2 billion RON (4.5 billion euro), representing $3.03 \%$ of GDP compared to $2.31 \%$ in December 2013. In the private pension funds (Pillar II), which on 31 December last year represented $95 \%$ of the total system, it was maintained a high annual growth rate characteristic to seven years of operation of $37.15 \%$.

93.2\% of assets were placed in Romania, 5.5\% invested in instruments of European Union and $1.3 \%$ were bonds issued by BERD and BEI. Private pension funds continue to be a financier of the Romanian state by investing primarily in securities issued by the Finance Ministry.

Given the internal and external evolution of financial environment, the strategic asset allocation of private pension funds has changed quite high lately. The share of bank deposits was halved, while the share of fixed income instruments, shares and investment funds have increased. The largest increase in 2014 was recorded for shares. The trend of reducing investments denominated in lei continued, increasing the European currency and Turkish lira. Currency risk was partially covered for the euro, the Hungarian forint, Polish zloty and US dollar using forward contracts concluded with banks.

Private pension funds investments in government bonds were almost entirely instruments issued by the Romanian state in RON, EUR and USD. Romanian corporate bonds had a slight increase in total corporate bonds.

The trend of increasing investments in Romanian equities continued in 2014 , administrators focusing mainly towards Romanian issuers and increased liquidity. Investments in shares of foreign issuers were more diversified.

And in 2014, pension funds represented the most deposits in Romanian banks, $90.78 \%$ of which is denominated in lei. The trend to reduce interest rates offered, due to expansionary monetary policy led administrators to halve the share of amounts invested in bank deposits, opting for other types of assets, mainly shares. The share of investment funds in total assets rose slightly, Romanian administrators preferring UCITS that invest in bonds and shares of UCITS from European Union and Romania.

The investment portfolio structure and their diversification, reflecting the risk diversification plays an important role in ensuring adequacy of income from private pensions.

\section{References}

1. Asfromania. Main page. Available at: www.asfromania.ro $(5 / 5 / 2016)$

2. CNPP. Main page. Available at: www.cnpp.ro (5/5/2016)

3. Colomeischi T. (2014) "Sistemul pensiilor din România din perspectivă matematică actuarială", Editura Didactică şi Pedagogică, ISBN 978-973-30-3657-9

4. Constantinescu D., Constantinescu M. (2005) - „Fonduri private de pensii”, Partea I, Ed. Bren, Bucureşti

5. CSSPP. Main page. Available at: www.csspp.ro (5/5/2016)

6. Institutul National de Statistica - INSSE - Anuare statistice pe anii 2013-2014. Available

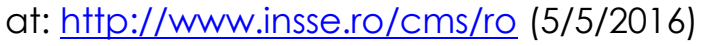




\section{About the authors}

Tudor Colomeischi Ph.D. works at the Department of Economy, Economic Informatics and Business from Economic Study and Public Administration Faculty, Stefan cel Mare University from Suceava. He graduated the courses of Mathematics Faculty at Bucharest University, class of 1997 and the courses of "Finance, Insurance, Banking and Stock Exchange" of "Bucharest University of Economic Studies", class of 2000. He holds a PhD in Economic Cybernetics, Statistics and Informatics from the "Bucharest University of Economic Studies", Bucharest, from 2012. His main abilities are: mathematics, applied mathematics in economy, actuarial mathematics and private pensions. His experience in research contracts: he was part of the research team in 4 contracted projects, all finalized. He is member of Mathematic Sciences Society of Romania. The author can be contacted at fudorcolomeischi@yahoo.ro.

Eugenia lancu is an Associate Professor Ph.D. at University Stefan cel Mare Suceava, at Faculty of Economics and Public Administration. Has a 20 years experience in research and teaching activities in the field of higher education. She is also author and co-author of 6 books, over 35 studies and scientific papers published in the country and abroad, indexed in international data base, being, at the same time, member in national and international associations. Areas of interest, Computer science, artificial intelligence, databases, neural networks, informatics systems design in business administration, economic informatics and mathematics, information technology management. The author can be contacted at eiancu@seap.usv.ro; eiancu56@yahoo.it. 